\title{
Comparative Design of Permanent Magnet Synchronous Motors for Low-Power Industrial Applications
}

\author{
H. YETIS, T. GOKTAS
}

\begin{abstract}
Permanent magnet synchronous motors (PMSMs) have superior features such as less volume and weight, long-life, high performance compared to induction motors. In this study, a comparative design of PMSMs is provided by considering a 2.2 $\mathrm{kW}$ induction motor nameplate parameters which is commonly used in industrial applications. A parametric analysis is used in order to design stator slot and magnet geometries of SurfaceMounted Permanent Magnet Synchronous (SPM) and Interior Permanent Magnet (IPM) Motors to get the high efficiency, low torque ripple. Ansys@Maxwell-2D software using time stepping finite element method is utilized to verify the advantages of designed motors compare to induction motors. In addition, material consumptions of both PMSMs and induction motor are compared to show the effectiveness of proposed motors in mechanically. It is shown that designed SPM and IPM motors have higher efficiency, lower torque ripple and volume than that of induction motors.
\end{abstract}

Index Terms-Interior permanent magnet synchronous (IPM) motor, motor design, parametric analysis, permanent magnet synchronous motors (PMSMs), surface-mounted synchronous (SPM) motor

\section{INTRODUCTION}

$\mathrm{T}$ HE IDEA of obtaining the required flux from magnets to produce the necessary torque in electrical machines is based on the 20th century [1-3]. The historical development of these motors is directly related to the advances in the technology of high-density permanent-magnet materials with sufficient remanent flux density and coercivity [4]. The high performance PMSMs which have a higher torque/power ratio can be designed using highly energy intensive magnets such as Neodymium-Iron-Boron (NdFeB) and Samarium-Cobalt (SmCo) magnets [5].

The permanent magnet synchronous motors (PMSMs) have superior features compared to induction motors such as high efficiency, less mechanical noise, direct drive, high

HICRET YETIS is with Department Electrical and Electronics Engineering University of Inonu University, Malatya, Turkey, (e-mail: hicretyetis@gmail.com).

(iD) https://orcid.org/0000-0002-3173-5611

TANER GOKTAS, is with Department Electrical and Electronics Engineering University of Inonu University, Malatya, Turkey, (e-mail: taner.goktas@inonu.edu.tr).

(iD https://orcid.org/0000-0002-8218-3239

Manuscript received April 30, 2020; accepted June 17, 2020.

DOI: $10.17694 /$ bajece.729751 performance even at low speeds, long-life time and less volume [6-10].

The rotor has permanent magnets (PMs) to produce the required torque as well as flux instead of excitation windings in PMSMs; thus the efficiency do increase due to elimination of copper losses and the operation and maintain costs reduces in PMSMs. That's why they are highly preferred in industrial applications [11-12].

The permanent magnet synchronous motors (PMSMs) are classified as two groups such as surface-mounted synchronous (SPM) motors and interior magnet synchronous (IPM) motors based on magnet positions on the rotor [13-14]. It is known that locating the magnets on the rotor surface provide simplicity in surface-mounted motors while IPM motors are mechanically more robust since its magnets are embedded into rotor. SPM motors are very popular in industrial applications due to their stator inductances independent of rotor position, simplicity of control and construction [15]. IPM motors offer a wide constant power speed range and can be overloaded at low and high speed than SPM motors [16].

Besides its superior advantages, a common drawback of the PMSMs is torque ripple [17-18]. There are several reasons such as harmonics in the back EMF; magnetic saturation, and controller effects which cause ripple on the torque in both PMSMs. [19]. In a SPM motor, cogging torque which is caused by the interaction between the magnets on the rotor surface and the steel teethes on the stator also contributes torque ripple. [6,20]. In IPM motor, torque ripple is generated as undesirable by product of the interaction between rotor and stator MMF waveform and the variation of magnetic reluctance between the flux barriers and slot teethes [21-23]. In the design process; slot / pole combination, stator slotting, magnet geometry and rotor structure should be designed carefully to decrease torque ripple.

The objective of this paper is to present PMSMs advantages compared to induction motor for low-power industrial applications. A sensitive design process is carried out to high efficiency and low torque ripple ratio PMSMs.

For this purpose, both IPM and SPM motors are comparatively designed using ANSYS@Maxwell-2D software. The $2.2 \mathrm{~kW}$ induction motor is selected as reference motor [24]. The parameters of the reference induction motor and proposed PMSMs are given in Table A. In order to design the optimal PMSMs, the parametric analysis is carried out through the RMxprt@Maxwell software. The designed 
PMSMs are analyzed in terms of torque ripple, efficiency, flux distribution, phase current and material consumption compared using Maxwell-2D transient solver. The transient finite element analysis (FEA) results show that two PMSMs designs have less volume, higher efficiency and lower torque ripple compared to reference induction motor.

\section{DESIGN PROCESS OF PERMANENT MAGNET SYNCHRONOUS MOTORS}

The output torque in PMSMs strongly depends on the remanent flux density of magnet. The $d-q$ equivalent circuit model is widely used since it simplifies the calculation of complex equations [25]. The electromagnetic torque $\left(T_{e m}\right)$ produced by PMSMs according to the d-q equivalent circuit model calculated as:

$$
T_{e m}=\frac{3}{2} p_{p}\left[\psi_{p m} i_{q}+\left(L_{d}-L_{q}\right) i_{d} i_{q}\right]
$$

where $P_{p}$ is the number of pole pairs, $\psi_{p m}$ is the permanent magnet flux linkage. The $i_{d}, i_{q}, L_{d}$ and $L_{q}$ represent stator $d-q$ axis currents and inductances, respectively. The terms $\left(\psi_{p m} i_{q}\right)$ and $\left(L_{d}-L_{q}\right) i_{d} i_{q}$ in Eq. (1) are related to magnet torque and reluctance torque, respectively. The $L_{d}$ and $L_{q}$ inductances are independent from the rotor position and they are approximately equal to each other in SPM motors, - but not IPM motors.

Based on Eq. (1), the produced electromagnetic torque in SPM motors $\left(T_{e m-S P M}\right)$ can be modified as in Eq. (2) since $L_{d}$ and $L_{q}$ are equal each other, thus eliminates the second term in Eq. (1) as follows:

$$
T_{e m_{S P M}}=\frac{3}{2} p_{p}\left[\psi_{p m} i_{q}\right]
$$

As seen from the Eq. (2), $L_{d}$ and $L_{q}$ inductances do not directly affect the torque generation in SPM motors On the contrary to SPM motors, the IPM motors can operate at high speeds due to embedding rotor magnets and have reluctance torque since $L_{d}$ and $L_{q}$ inductances are different from each other due to positions of magnet as shown in Fig. 1. The existence of reluctance torque in IPM motors provides high torque/power ratio at variable speed applications and it is possible to use low-cost permanent magnets which has lower magnetic energy density due to reluctance torque component [15]. It is clear that the electromagnetic torques includes the reluctance torque component as in Eq. (1) compared to that of SPM motors.

As a result, it should be considered that some electrical and mechanical parameters such as slot/pole combination, winding distribution, magnetic saturation, stator slot structure, magnet shape and dimensions to design high performance PMSMs.

\section{A. Design Parameters}

Electrical and mechanical parameters such as power, torque, speed, armature current density, rotor and stator material type, stator and rotor dimensions, etc. are taken into account in order to design both SPM and IPM motors. It is well known that the output power is proportional to stator and rotor outer
TABLE I

PARAMETERS OF DESIGNED MOTORS

\begin{tabular}{|c|c|c|c|}
\hline Parameter & Unit & SPM & IPM \\
\hline Stator and rotor core material & & \multicolumn{2}{|c|}{1008} \\
\hline Armature current density & $A / \mathrm{mm}^{2}$ & \multicolumn{2}{|c|}{5.7} \\
\hline Slot number & & 39 & 33 \\
\hline Pole number & & 28 & 10 \\
\hline Stator outer diameter & $m m$ & \multicolumn{2}{|c|}{122} \\
\hline Rotor outer diameter & $m m$ & \multicolumn{2}{|c|}{63} \\
\hline Rotor inner diameter & $m m$ & \multicolumn{2}{|c|}{26} \\
\hline Air gap & $m m$ & \multicolumn{2}{|c|}{0.5} \\
\hline Stator and rotor skew angle & degree & \multicolumn{2}{|c|}{0} \\
\hline Stack length & $m m$ & 65 & 58 \\
\hline
\end{tabular}

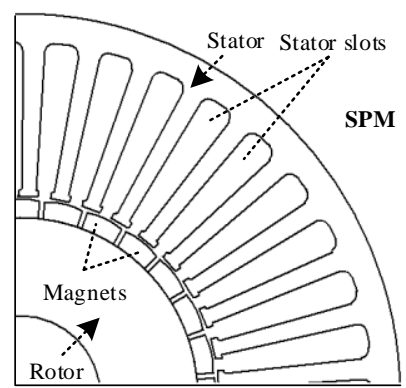

(a)

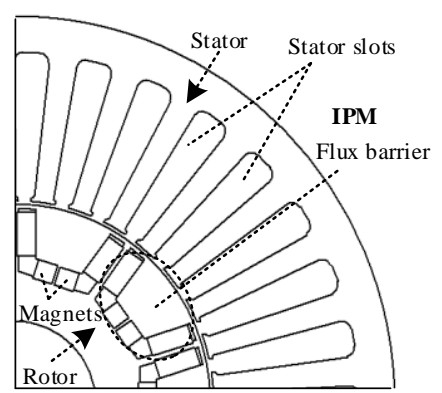

(b)
Fig.1. Main geometry of designed motors; (a) SPM, (b) IPM

diameter in any motor. The outer diameter of stator and rotor and stack length in PMSMs can be lower than that of IMs since they have their own excitation due to permanent magnets. That's why, stator and rotor outer diameters in PMSMs are selected as $122 \mathrm{~mm}$ and $63 \mathrm{~mm}$, respectively to get the required output power. Since the reluctance torque component contributes positively to the output torque, the stack length value of the IPM motor can be chosen smaller compared to SPM motor. Thus, the stack lengths are selected as $65 \mathrm{~mm}$ and $58 \mathrm{~mm}$ for SPM and IPM motors, respectively. In both designs, NdFe 35 magnets which have high energy density have been used. The Air gap value is selected as smaller as possible mechanically such as $0.5 \mathrm{~mm}$ to minimize the leakage flux distribution in the air-gap.

Each magnet forms a pole in SPM motor while each flux barrier forms a pole in IPM motor. Since the area on the inner surface of the IPM rotor is limited, the number of poles cannot be selected as high as in the SPM motor. In addition, number of slot in PM motors should be determined according to number of pole depending on the motor type because the slot/pole ratio can affect the dynamic motor performance as well. Based on the possible pole/slot combinations [26], the number of slot and poles are selected as 39 slot / 28 pole for SPM motor and 33 slot / 10 pole for IPM motor. The coil pitch is 1 and 3 for SPM and IPM motor, respectively since it is dependent on slot/pole ratio of the designed motors. The designed motor parameters by considering electrical parameters of reference induction motor (see Appendix- Table A) are summarized at Table I. 
TABLE II

THE LIMITS OF INPUT PARAMETERS AND STEP SIZE

\begin{tabular}{|c|c|c|c|}
\hline & Unit & Ranges & Increment \\
\hline Slot length (Hs2) & $m m$ & $15<\mathrm{Hs} 2<25$ & $\Delta_{H s 2}=0.25$ \\
\hline Slot width-1 (Bs1) & $m m$ & $2.75<\mathrm{Bs} 1<5$ & $\Delta_{B s 1}=0.1$ \\
\hline Slot width-2 (Bs2) & $m m$ & $3<\mathrm{Bs} 2<8$ & $\Delta_{B s 2}=0.1$ \\
\hline $\begin{array}{c}\text { Slot opening } \\
\text { (Bs0) }\end{array}$ & $m m$ & $1.25<\mathrm{Bs} 0<2.75$ & $\Delta_{B s 0}=0.1$ \\
\hline $\begin{array}{c}\text { Magnet } \\
\text { Geometry of SPM }\end{array}$ & Unit & Ranges & Increment \\
\hline $\begin{array}{c}\text { Magnet thickness } \\
\text { (Mt) }\end{array}$ & $m m$ & $1.5<\mathrm{Mt}<5$ & $\Delta_{M t}=0.25$ \\
\hline $\begin{array}{c}\text { Magnet width } \\
\text { (emb) }\end{array}$ & - & $0.4<$ emb $<0.95$ & $\Delta_{e m b}=0.02$ \\
\hline $\begin{array}{c}\text { Magnet } \\
\text { Geometry of IPM }\end{array}$ & Unit & Ranges & Increment \\
\hline $\begin{array}{c}\text { Magnet thickness } \\
\text { (Mt) }\end{array}$ & $m m$ & $1<\mathrm{Mt}<3$ & $\Delta_{B 1}=0.1$ \\
\hline $\begin{array}{c}\text { Magnet width } \\
\text { (Mw) }\end{array}$ & $m m$ & $13<\mathrm{Mw}<22$ & $\Delta_{M w}=0.1$ \\
\hline
\end{tabular}

\section{B. Parametric Analysis}

Parametric analysis is an approach of the influence of different geometric and physical parameters on the system performance. The effect of each input parameter on the output values is examined by changing parameters in a certain number of step. The input parameters are modified to provide the most optimal output values such as efficiency, torque and flux density in motors. In order to carry out parametric analysis, the RMxprt@ ANSYS software is used for both PMSMs design process. The selected input parameters for parametric analysis are slot length, slot width, slot opening, magnet thickness and magnet width since they significantly affect the motor performance in PMSMs [27-28]. The output parameters are motor efficiency and stator flux density and cogging torque to design the motor more efficiently. It should be noted that there is no cogging torque in IPM motor.

Table II shows that the limits of input parameters and incremental step size for each parameters in parametric analysis. The incremental step size of each analysis is well enough to get the optimal results. The dimensions of the stator slots are modified as to limit the current density $J=5.7 \mathrm{~A} / \mathrm{mm}^{2}$ and maximum flux density $B_{\max }=1.8$ Tesla in order to avoid magnetic saturation by considering B-H curve of used materials. Fig. 4. shows the parametric analysis results for PMSMs.

As can see from the Fig. 4 (Stator length (Hs2) parameter), when the slot length (Hs2) increases the efficiency raises at a certain point. In IPM motor, efficiency parameter is getting decreased after Hs2 $=22.5 \mathrm{~mm}$ so $\mathrm{Hs} 2$ value should be carefully selected considered as slot topology. Slot length (Hs2) also affects the stator flux density. As seen, when the slot length increases, stator flux density is getting lower for both SPM and IPM motors. It is clearly seen that slot length (Hs2) has no more effect on the cogging torque in SPM motor.

Slot width (Bs1) can affect the motor dynamic performance as well. As can be seen from the Fig.4 (Slot width-1 (Bs1)

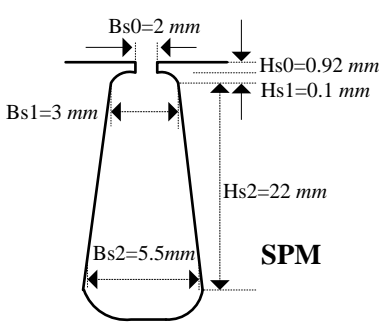

(a)

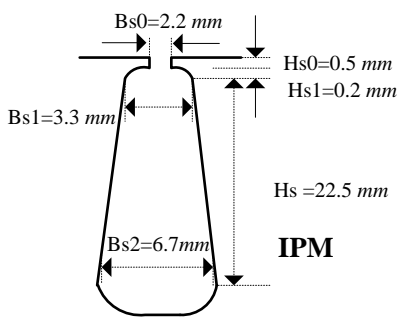

(b)
Fig.2 Slot geometries of a) SPM motor b) IPM motor

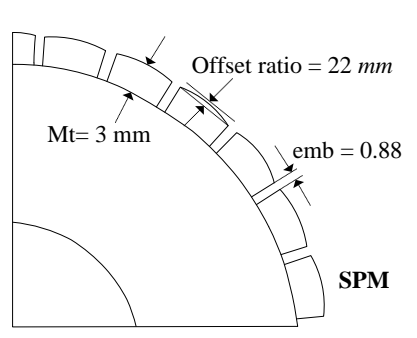

(a)

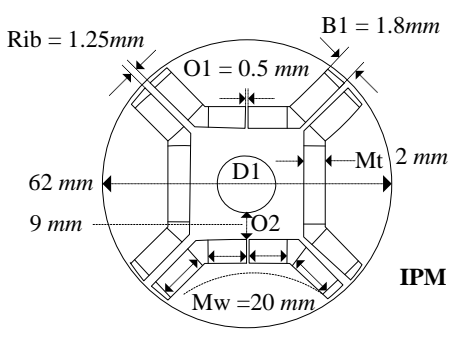

(b)
Fig.3 Magnet geometries of a) SPM motor b) IPM motor

parameter), the efficiency gets lower values if the slot with increases whereas flux density raises depending on increasing Bs1 values. Cogging torque gets minimized while slot width-1 increases.

Based on the parametric analysis results, slot width-2 (Bs2) strongly affect the stator flux density, -but not efficiency as seen Fig. 4 (Slot width-2 (Bs2) parameter). It is also seen that cogging torque in SPM motors decreases with the increasing slot width-2 (Bs2) values.

The parameter of slot opening ( $\mathrm{Bs} 0)$ has no significantly effect on efficiency and stator flux density in both PM motors as seen from the Fig.4 (Slot opening (Bs0) parameter). The cogging torque values change depending on different slot opening (Bs0) parameters.

Based on the parametric results, in order to limit $\mathrm{B}_{\max }=1.8$ Tesla to avoid the magnetic saturation, the parameters Hs2, Bs1 and Bs2 are selected as $22 \mathrm{~mm}, 3 \mathrm{~mm}, 5.5 \mathrm{~mm}$ for SPM motor and $22.5 \mathrm{~mm}, 3.3 \mathrm{~mm}$, and 6.7 for IPM motor, respectively. Other slot geometry parameters are also selected through the parametric analysis results to get the optimum values of each specified motor performance parameters as seen From the Fig. 2.

Fig. 3. shows the magnet geometries for both PMSMs. The single flux barrier layered $\mathrm{U}$-shape rotor type is selected as to get the high torque/power ratio for IPM motor. As seen from the figure, magnet thickness, embrace ratio, and shape of magnets are taken into account to design the rotor. It is clearly seen from the Fig.4 (Magnet thickness (Mt) parameter) that if the magnet thickness (Mt) increase, the efficiency and flux density raise up since flux density is proportional to magnet volume as known. The cogging torque is almost the same with the increasing magnet thickness values in SPM motor.

Magnet width (ebm for SPM and Mw for IPM) has also affect the motor performance. As seen from the Fig. 4. (Magnet width (ebm\&Mw) parameter), if the magnet width (ebm\&Mw) increase then the efficiency and stator flux density 

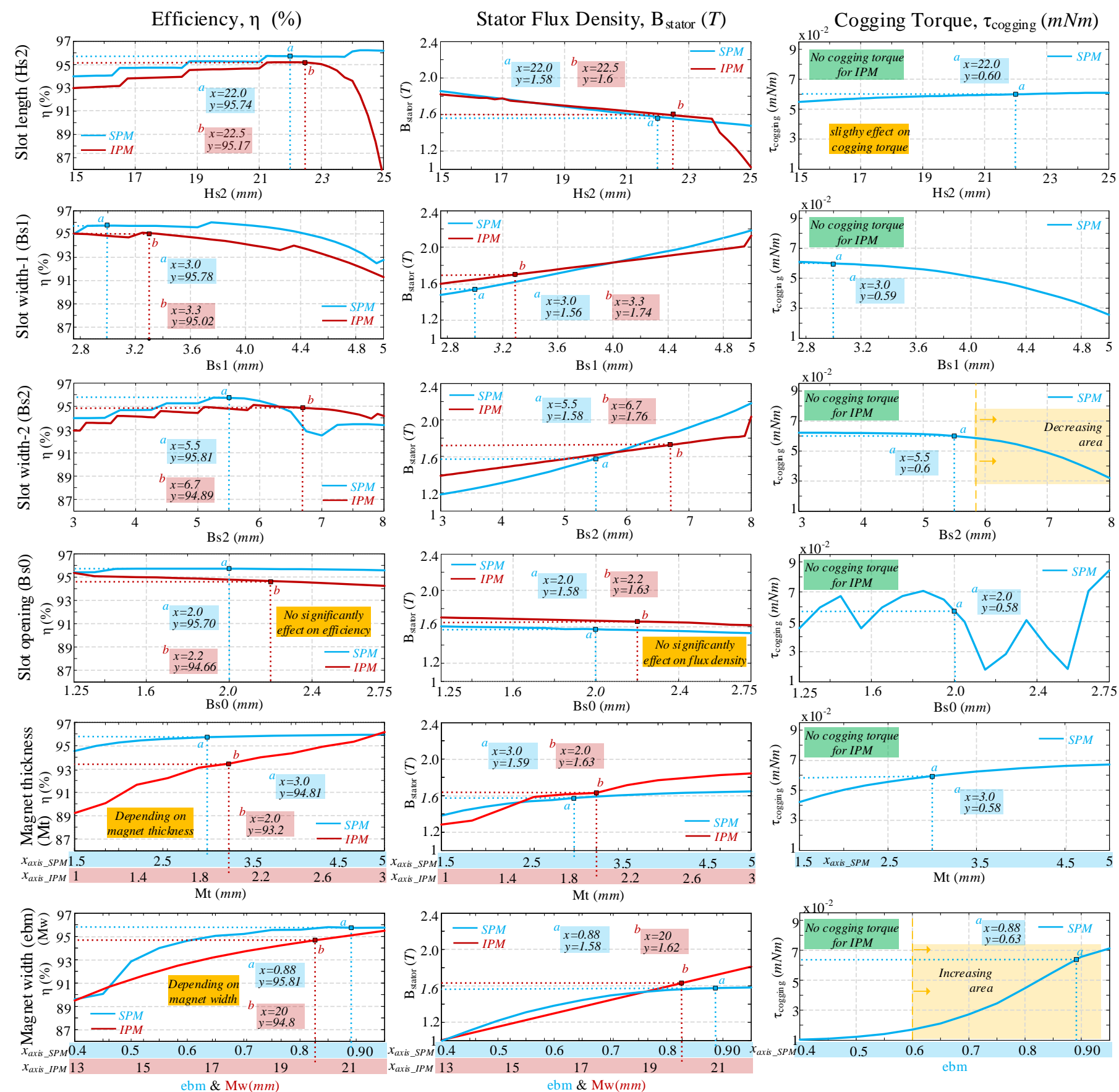

Fig. 4 Parametric analysis results of SPM (blue-solid line) and IPM (red-solid line) motor

raises depending on magnet width values. However, cogging torque is dramatically increases with the increase magnet width values.

In order to select the optimal values of these parameters, it should be considered that maximum flux density is lower than specified value $1.8 \mathrm{Tesla}$. The parameters $\mathrm{Mt}$ and ebm are selected as $3 \mathrm{~mm}$ and 0.88 for SPM motor. In IPM motor Mt and $\mathrm{Mw}$ are selected as $2 \mathrm{~mm}, 20 \mathrm{~mm}$.

Based on the parametric analysis results, it has seen that all stator slot and rotor magnet geometries is chosen in order to limit the stator flux density at $B_{\max }=1.8$ Tesla for both two motors. It has been concluded that some of rotor parameters such as magnet thickness (Mt) and magnet width (ebm\&Mw) has more impact on motor efficiency and flux density while some stator slot parameters such as slot width-2(Bs2) and slot width-1 (Bs1) affect flux density in SPM and IPM motors.

\section{ANALYSIS RESULTS}

In order to see the performance of designed motors compared to reference induction motor, both PM motors and induction motor have been analyzed through the ANSYS@ Maxwell software in transient time step. The time step is 0.7 msec to get the accurate results in simulations. Both PM motors and reference IM are driven in the same pure 3-phase sinusoidal voltage $\left(V_{\text {applied }}=380 \mathrm{~V}\right)$ and loaded at the same 

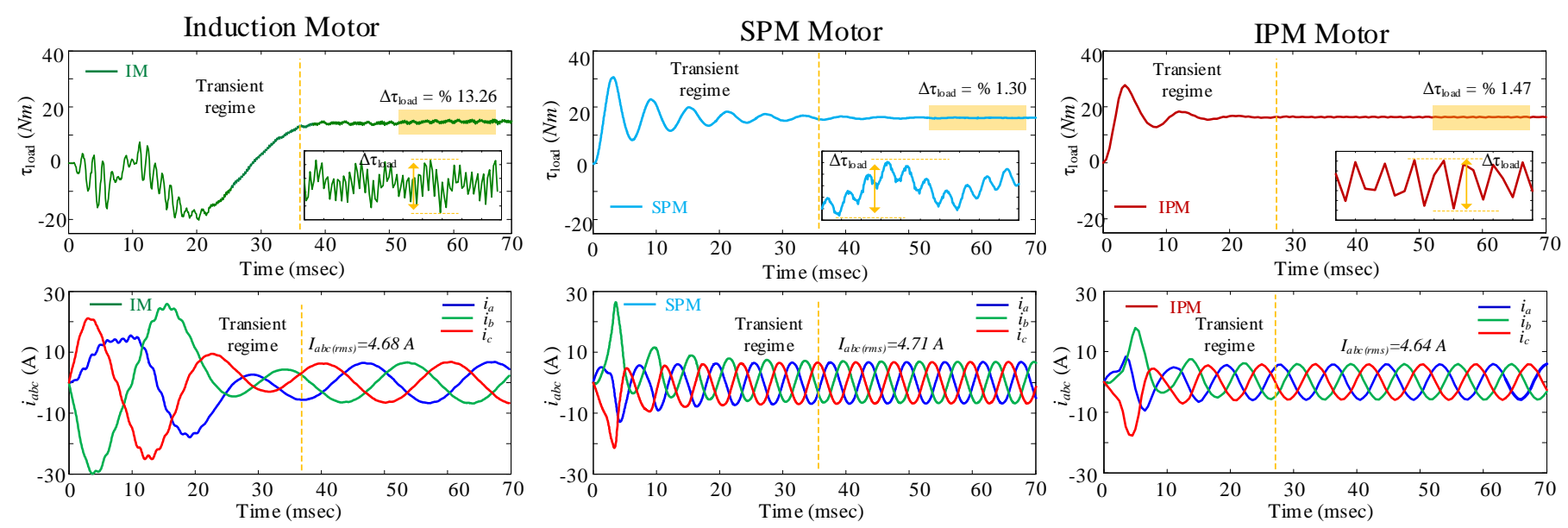

Fig. 5. Torque and Phase currents of a) Induction motor b) SPM motor c) IPM motor

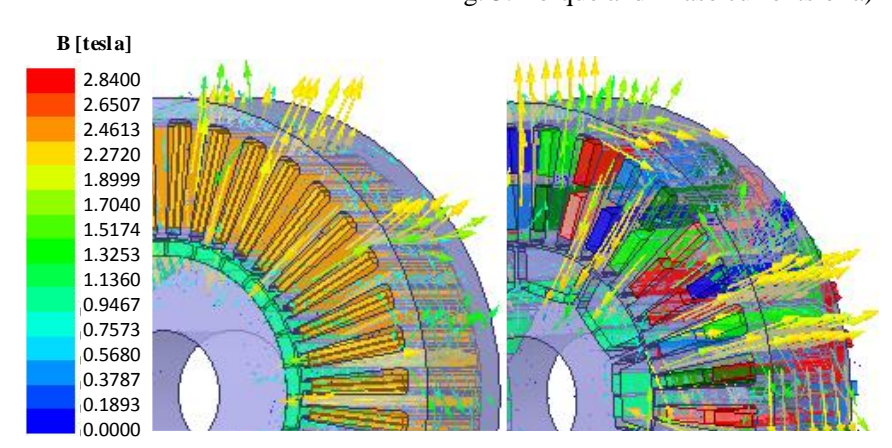

Fig. 6. The 3D view and flux vectors of a) SPM b) IPM motor

B [tesla]
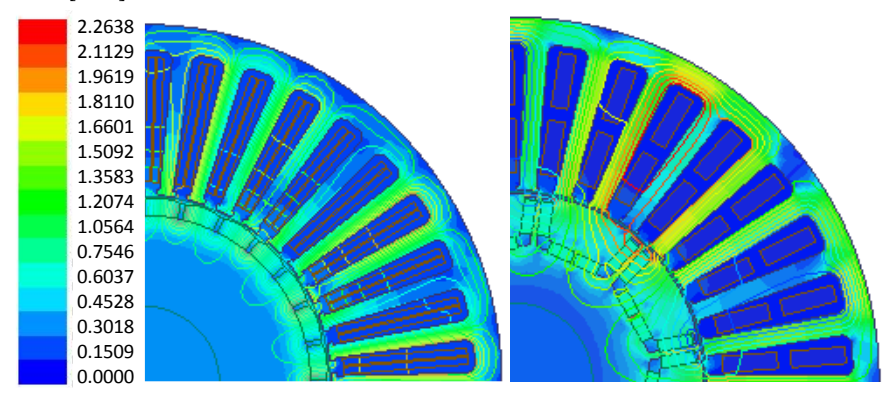

Fig. 7. Magnetic flux density of a) SPM b) IPM motor

torque and output power to compare the dynamic performance of all motors. The torque and torque ripple, stator phase currents, efficiency and material consumption are examined for all motors to see the advantages of PM motors compare than reference induction motor.

Fig. 6 shows that 3D view of designed SPM and IPM motor. It can be seen that flux vectors in PM motors are well oriented along with the rotor poles. It is clear that designed SPM and IPM motors have lower volume and size compared than induction motor since the have their own excitation in the rotor. The stator outer diameter and stack length of PM motors are lower than that of induction motor as seen from Table III. Flux density and flux vector of designed motors are shown in Fig. 7. As can be seen from the figure that there is no magnetic saturation in designed PM motors (see Appendix- Fig. a B-H curve of used material).

Fig. 5 shows that torque and phase currents of SPM, IPM and IM motors to see the effectiveness of PM motors. As seen from the Fig.5 that the torque ripple of PM motors are lower
TABLE III

PARAMETERS OF MOTORS

\begin{tabular}{|c|c|c|c|c|}
\hline Parameters & Unit & $\begin{array}{c}\text { Induction } \\
\text { motor }\end{array}$ & $\begin{array}{c}\text { SPM } \\
\text { motor }\end{array}$ & $\begin{array}{c}\text { IPM } \\
\text { motor }\end{array}$ \\
\hline Efficiency & $\%$ & 88.97 & 95.71 & 94.51 \\
\hline Torque ripple & $\%$ & 13.26 & 1.30 & 1.47 \\
\hline Stator outer diameter & $\mathrm{mm}$ & 145 & 122 & 122 \\
\hline Stack length & $\mathrm{mm}$ & 110 & 65 & 58 \\
\hline
\end{tabular}

TABLE IV

METARIAL CONSUMPTION OF MOTORS

\begin{tabular}{|c|c|c|c|c|}
\hline Mass & Unit & $\begin{array}{c}\text { Induction } \\
\text { Motor }\end{array}$ & $\begin{array}{c}\text { SPM } \\
\text { motor }\end{array}$ & $\begin{array}{c}\text { IPM } \\
\text { motor }\end{array}$ \\
\hline Stator core & $k g$ & 6.1476 & 2.2359 & 2.081 \\
\hline Rotor core & $k g$ & 3.0647 & 1.0133 & 0.929 \\
\hline Stator winding & $k g$ & 2.3262 & 1.4367 & 1.444 \\
\hline Rotor bar & $k g$ & 0.6759 & - & - \\
\hline Rotor magnet & $k g$ & - & 0.2319 & 0.1716 \\
\hline Total & $k g$ & 12.211 & 4.9179 & 4.627 \\
\hline
\end{tabular}

than reference induction motor at the same loaded conditions. The phase currents approximately have the same RMS values for all motor which results to limit current density at specified value $\left(\mathrm{J}=5.7 \mathrm{~A} / \mathrm{mm}^{2}\right)$. If the efficiency is analyzed for all motors, it is clearly seen from the Table III. that efficiency has increased by almost 5\% compared to that of IM. Table IV. shows the material consumption of designed PM motors and reference induction motor. As seen from the Table IV. that total mass of SPM and IPM motor are reduced by approximately $60 \%$ compared than the reference induction motor. However, it should be considered that the high price of magnet used (NdFe35) will increase the total cost of PM motors. Although the total cost increases, the additional production costs will be compensated in the medium or long term as the PM motors efficiency are higher than IMs.

It is concluded that the designed SPM and IPM motors have higher efficiency, lower torque ripple, volume and mass compared than induction motor. 


\section{CONCLUSIONS}

The design stages of SPM and IPM motors are described in detail and stator\&rotor geometries are determined through the parametric analysis. Torque and torque ripple, efficiency, phase currents and material consumption of designed PM motors are compared to reference induction motor that is utilized for low power applications. Along with the parametric optimization process, the efficiency of PM motors has been increased while torque ripple, motor volume as well as motor weights have been decreased compared than that of induction motor. The designed PM motors enable very practical solutions due to its energy efficiency and performance in low power industrial applications.

\section{APPENDIX}

TABLE A

PARAMETERS OF INDUCTION MOTOR

\begin{tabular}{|l|l|}
\hline Motor name: Induction motor & Item \\
\hline Rated power & $2.2 \mathrm{~kW}$ \\
\hline Rated speed & $1420 \mathrm{rpm}$ \\
\hline Rated torque & $14.8 \mathrm{Nm}$ \\
\hline Number of slot/pole & $36 / 4$ \\
\hline Stator outer diameter & $145 \mathrm{~mm}$ \\
\hline Rotor outer diameter & $88 \mathrm{~mm}$ \\
\hline Rotor inner diameter & $35 \mathrm{~mm}$ \\
\hline Stack length & $110 \mathrm{~mm}$ \\
\hline Air gap & $0.25 \mathrm{~mm}$ \\
\hline Armature current density & $5.7 \mathrm{~A} / \mathrm{mm}^{2}$ \\
\hline Winding type & Distributed \\
\hline Coil span & 8 \\
\hline Stator and rotor core material & 1008 \\
\hline Stator skew angle & $0^{\circ}$ \\
\hline Rotor skew angle & $12.86^{\circ}$ \\
\hline Efficiency & $88.97 \%$ \\
\hline Torque ripple & $13.26 \%$ \\
\hline
\end{tabular}

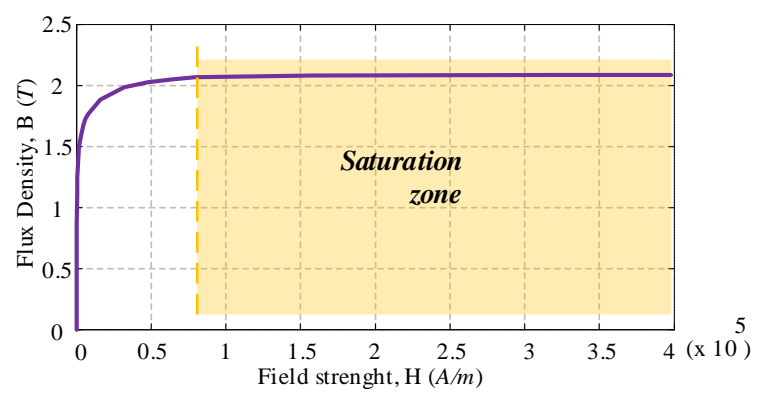

Fig. a. B-H curve of stator and rotor core material (Steel_1008)

\section{REFERENCES}

[1] T.J.E. Miller, T. W. Neumann, E Richter, "A permanent magnet excited high efficiency synchronous motor with line-start capability,"18th Ind. Appl. Soc. Annu. Meeting, 1983, pp. 455-461.

[2] G.R. Slemon, "On the Design of High-Performance Surface-Mounted PM Motors", IEEE Transactions on Industry Applications, Vol. 30, No. 1, Jan./Feb. 1994, pp. 134-140.
[3] M.A. Rahman, "Analysis of Brushless Permanent Magnet Synchronous Motors" IEEE Transactions on Industry Applications, Vol. 43, No. 2, April 1996, pp.256-267.

[4] M.A. Rahman, G. Slemon, "Promising Applications of Neodymium Boron Iron Magnets in Electrical Machines" IEEE Transactions on Magnetics, Vol. 21, No. 5, 1985, pp.1712-1716.

[5] G. Pellegrino, T.M. Jahns,N. Bianchi, W.L. Soong, F. Cupertino, "The Rediscovery of Synchronous Reluctance and Ferrite Permanent Magnet Motors", Tutorial Course Notes, Springer Nature, Switzerland, 2016.

[6] N. Bianchi, S. Bolognani, "Design Techniques for Reducing the Cogging Torque in Surface-Mounted PM Motors", IEEE Transactions on Industry Applications, Vol. 38, No. 5, Sep./Oct. 2002, pp.1259-1265.

[7] E. Carraro, M. Degano, M. Morandin, N. Bianchi, "PM Synchronous Machine Comparison for Light Electric Vehicles", IEEE International Electric Vehicle Conference (IEVC), 17-19 December 2014, Florence, pp. $1-8$.

[8] N. Bianchi, S. Bolognani, P. Frare, "Design Criteria for High-Efficiency SPM Synchronous Motors", IEEE Transactions on Energy Conversion, Vol. 21, No. 2, June 2006, pp.396-404.

[9] C. He, T. Wu, "Analysis and Design of Surface Permanent Magnet Synchronous Motor and Generator", CES Transactions on Electrical Machines and Systems, Vol. 3, No. 1, March 2019, pp. 94-100.

[10] R. Celikel and M. Ozdemir, "Control of a Three-Phase Boost Rectifier for High-Speed BLDC Generators Used in Flywheel Energy Storage System" International Conference on Advanced Technology \& Sciences (ICAT'16), 2016, pp. 530-535.

[11] V. Sarac, D. Iliev, "Synchronous Motors of Permanent Magnet Compared to Asynchronous Induction Motor", Electrotehnica, Electronica, Automatica (EEA), Vol. 65, No. 4, 2017, pp. 51-58.

[12] R. Celikel, "Speed Control of BLDC Using NARMA-L2 Controller in Single Link Manipulator", Balkan Journal of Electrical and Computer Engineering, Vol. 7, No. 2, April 2019, pp. 141-148.

[13] Y. Yang, S. Castano, R. Yang, M. Kasprzak, B. Bilgin, A. Sathyan, H. Dadkhah, A. Emadi, "Design and Comparison of Interior Permanent Magnet Motor Topologies for Traction Applications" IEEE Transactions on Transportation Electrification, Vol, 3, No 1, 2017, pp. 87-97.

[14] H. Yetis, E. Mese, M. Biyikli, "Design and Comparison of Ferrite Based IPM and NdFeB Based SPM Synchronous Motors for Gearless Elevator Systems", International Conference on Electrical Machines (ICEM), 3-6 Sep.2018, Alexandroupoli, pp.635-641.

[15] G. Pellegrino, A. Vagati, P. Guglielmi, B. Boazzo, "Performance Comparison Between Surface-Mounted and Interior PM Motor Drives for Electric Vehicle Application", IEEE Transactions On Industry Applications, Vol. 59, No 2, 2012, pp. 803-811.

[16] A. M. El-Refaie, T. M. Jahns, "Comparison of synchronous PM machine types for wide constant-power speed range operation", 40th Conf. Rec. IEEE IAS Annu. Meeting, Oct. 2-6, 2005, vol. 2, pp. 1015-1022.

[17] R. Islam, I. Husain, A. Fardoun and K. McLaughlin, "PermanentMagnet Synchronous Motor Magnet Designs With Skewing for Torque Ripple and Cogging Torque Reduction", IEEE Transactions on Industry Applications, Vol. 45, No. 1, 2009, pp. 152-160.

[18] R. Celikel, O. Aydogmus, "A torque ripple minimization method for brushless DC motor in high speed applications using buck boost topology" Journal of Enginering Research, Vol. 7, No. 3, September2019, pp. 200-214.

[19] M. S. Islam, S. Mir, T. Sebastian and S. Underwood, "Design considerations of sinusoidally excited permanent-magnet Machines for low-torque-ripple applications", IEEE Transactions on Industry Applications, Vol. 41, No. 4, July-Aug. 2005, pp. 955-962.

[20] T. $\mathrm{Li}$ and G. Slemon, "Reduction of cogging torque in permanent magnet motors IEEE Transactions on Magnetics, ,Vol. 24, No 6, Nov. 1988, pp. 2901-2903.

[21] S. H. Han, T. M. Jahns and W. L. Soong, "Torque Ripple Reduction in Interior Permanent Magnet Synchronous Machines Using the Principle of Mutual Harmonics Exclusion", IEEE Industry Applications Annual Meeting, Sep. 2007, pp.558-565.

[22] S. Han, T. M. Jahns, W. L. Soong, M. K. Güven and M. S. Illindala, "Torque Ripple Reduction in Interior Permanent Magnet Synchronous Machines Using Stators With Odd Number of Slots Per Pole Pair", IEEE Transactions on Energy Conversion, Vol. 25, No. 1, March 2010, pp. 118-127. 
[23] M. Sanada, K. Hiramoto, S. Morimoto, Y. Takeda, "Torque Ripple Improvement for Synchronous Reluctance Motor Using an Asymmetric Flux Barrier Arrangement", IEEE Transactions On Industry Applications, Vol. 40, No. 4, Jul./Aug. 2004, pp. 1076-1082.

[24] T. Goktas, M. Arkan, "Diagnosis of Broken Rotor Fault in Inverter-Fed IM by Using Analytical Signal Angular Fluctuation", 16th International Power Electronics and Motion Control Conference and Exposition, 2124 Sept 2014, Antalya, pp. 1-6.

[25] D.Y. Ohm, "Dynamic Model of PM Synchronous Motors", Drivetech, Inc., Blacksburg, Virginia, 1997.

[26] J.R. Hendershot, T.J.E. Miller, "Design of brushless permanent magnet motors", Magna Physics Publishing and Clarendon Press, Oxford,1994.

[27] M. Ayaz, M. Tezcan, E. Mese, K. Y1lmaz, "Parametric Optimization of Permanent Magnet Synchronous Machines" in Proc. 6th International Conference on Control Engineering \& Information Technology (CEIT), 25-27 Oct. 2018, İstanbul, pp. 1-6.

[28] C. Lu, S. Ferrari, G. Pellegrino, C. Bianchini, M. Davoli, "Parametric Design Method for SPM Machines Including Rounded PM Shape", in Proc. 2017 IEEE Energy Conversion Congress and Exposition (ECCE), 1-5 Oct. 2017, Cincinnati, pp. 4309-4315.

\section{BIOGRAPHIES}

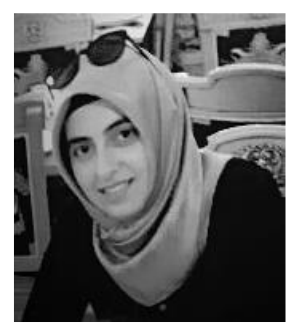

HICRET YETIS received B.S. and M.S. degrees in electrical engineering from Yildiz Technical University, Istanbul, Turkey, in 2013, 2017, respectively. Since 2018 she has been a student of Ph.D. degree in Inonu University, Malatya, in the Electrical and Electronics Engineering department. Her research interests include design of electric machines.

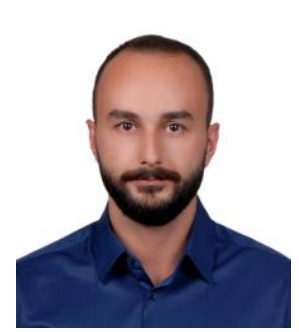

TANER GOKTAS received B.S and M.S degrees in electrical engineering from Firat University, Elazig, Turkey, in 2006 and 2010, respectively, and the $\mathrm{Ph} . \mathrm{D}$. degree in Electrical Engineering from the Inonu University, Malatya, Turkey, in 2015. He was a visiting scholar in the Power Electronic and Drives Lab, University of Texas at Dallas from 2014 to 2015. Since 2016, he has been with Inonu University as Assistant Professor. His research interests include electric machines drives, condition monitoring, motor design and diagnostic techniques in electric machines. 